\title{
Guest Workers' Remittances and Output Fluctuations in Host and Home Countries: The Case of Remittances from Turkish Workers in Germany
}

\section{SERDAR SAYAN}

To cite this article: SERDAR SAYAN (2004) Guest Workers' Remittances and Output Fluctuations in Host and Home Countries: The Case of Remittances from Turkish Workers in Germany, Emerging Markets Finance and Trade, 40:6, 68-81

To link to this article: https://doi.org/10.1080/1540496X.2004.11052590

曲 Published online: 07 Dec 2014.

Submit your article to this journal $₫$

Џ Article views: 69

Citing articles: 1 View citing articles ¿ 
Emerging Markets Finance and Trade, vol. 40, no. 6, November-December 2004, pp. 68-81.

(C) 2004 M.E. Sharpe, Inc. All rights reserved.

ISSN 1540-496X/2004\$9.50+0.00.

SERDAR SAYAN

\title{
Guest Workers' Remittances and Output Fluctuations in Host and Home Countries
}

\author{
The Case of Remittances from Turkish Workers \\ in Germany
}

\begin{abstract}
Over the past decades, different Mediterranean countries have sent considerable numbers of workers to the EU area, generating sizable amounts of foreign exchange receipts through the remittances these guest workers have transferred back home. In some instances, however, the share of remittances in foreign exchange receipts has risen so high as to cause concern for policymakers, as they imply potentially serious effects on macroeconomic balances following sudden drops or jumps in remittances. Despite the importance of implications of the volatility of remittance receipts, the current literature severely lacks thorough investigations into the sources of this volatility. This paper aims to help fill this gap in the literature by documenting some key business cycle properties of workers' remittances received by the Turkish economy. More specifically, the paper investigates whether there is a relationship between the amount of remittances sent to Turkey by the large number of Turkish workers living and working in Germany, and up-and downswings that Turkish and German economies experience. For this purpose, regularities between fluctuations in the national outputs of respective economies and remittance flows to Turkey are analyzed by using time series data, and implications of results for the Turkish economy are discussed.
\end{abstract}

Key words: business cycles, Germany, Turkey, workers' remittances.

Over the past decades, such Mediterranean countries as Albania, Egypt, Lebanon, Morocco, Tunisia, and Turkey have sent considerable numbers of workers to the

Serdar Sayan (sayan@bilkent.edu.tr) is an associate professor in the Department of Economics, Bilkent University, Ankara, Turkey. The author is grateful to Ebru Yuksel for her skillful research assistance.

68 
European Union (EU) area. ${ }^{1}$ This has not only reduced high unemployment rates encountered by surplus-labor countries around the Mediterranean, but it has also created a significant source of foreign exchange for these countries. The remittances sent by these emigrant or guest workers to their relatives back home have indeed reached sizable amounts, ${ }^{2}$ largely contributing to relaxation of the hard currency constraints facing the countries that sent them away (Collinson 1993; Giubilaro 1997; Straubhaar 1986). Growing steadily after the 1960s, remittance flows have become the second major source of external financing (after foreign direct investment [FDI]) for developing countries. Consistent with this growth and the increasing significance of these flows for recipient countries, an extensive literature on remittances has emerged. Whereas one branch of this literature has focused on microeconomic determinants of remittance flows at the household level, the other branch has concentrated on their determinants and economy-wide effects at a macro level (for more detailed surveys of the relevant literature, see Buch et al. 2002 and Chami et al. 2003).

Remittances are essentially transferred out of the savings of the emigrant workers. An emigrant worker who earns more than enough to cover his own living expenses as well as the expenditures required to maintain the standards of living of his relatives back home faces a continuum of choices concerning the share of additional funds to be transferred to his home country. ${ }^{3}$ Once the living expenses are accounted for, what percentage of the remaining savings will be placed on assets in the home country or abroad is a decision requiring a comparison of relative returns on these assets. Thus, the branch of existing literature with a macroeconomic focus either considers determinants of saving and remittance behavior of emigrant worker such as interest and exchange rate differentials (see, e.g., ElSakka and Mcnabb 1999; Faini 1994; Lianos 1997; Straubhaar 1986; Wahba 1991), or investigates the effects of remittances on the receiving economies (see, e.g., Glytsos 1993, 2002; Straubhaar 1985). While the evidence in the literature concerning their macroeconomic determinants is mixed, there is greater agreement on the significance of remittance flows as a source of external financing for many surplus-labor economies. ${ }^{4}$ Whatever determinants and macroeconomic conditions induce these flows, they often make marked contributions to the payments balances of receiving economies that are typically in a constant search for external financing.

For Lebanon, for example, official remittance receipts were as high as 38.8 percent of gross domestic product (GDP) during the 1990s. For Egypt and Morocco, this ratio was between 5 and 10 percent, and Greece, Portugal, and Tunisia fell into the same group with official remittance receipts to GDP ratios of 1 to 5 percent (Neyapti 2004). Likewise, remittances received by Turkey, one of the top remittance receivers in the world, corresponded to 2.3 percent of its GDP and 10.6 percent of its export revenues, and represented more than six times the amount this country received in FDI in 1999. In the case of Albania, remittance receipts amounted to about 10 percent of the GDP, ranking this country fifth in the world 
by this criterion, and corresponded to more than two times its export earnings and more than nine times the FDI the country attracted in 1999.5

Such high shares imply a high degree of dependence on remittances as a source of foreign exchange receipts. Even though remittances have been relatively more stable than private capital and FDI flows (Neyapti 2004; Ratha 2003), these high shares are a cause for concern, because they increase the capacity of swings in remittance flows to produce fluctuations in current account balances, with serious macroeconomic effects. ${ }^{6}$ A strong case in point can be made by considering the disastrous consequences of the Gulf War for the economies receiving large amounts of remittances from Iraq and Kuwait. Following the invasion of Kuwait by Iraq in 1990 , the nations that sent large numbers of emigrant workers to these countries faced a sudden cut in remittance receipts. Egypt, for example, was forced to forfeit $\$ 2$ billion it expected to receive from Egyptian workers in Kuwait in 1990, plus another $\$ 13$ billion in unremitted savings of these workers, not to mention the lost remittances in the following years. The magnitude of Egypt's loss of much-needed foreign currency can be better understood if one remembers that the stock of unremitted savings lost in Kuwait corresponded to 46 percent of the officially recorded remittances to Egypt during the previous decade (Wahba 1991).

The Gulf War can perhaps be considered a rather extreme situation. Yet the remittance flows have always fluctuated, though to a lesser extent, even in the absence of wars, often causing severe disturbances to the macroeconomic balances of labor-exporting countries that rely heavily on remittances. Following the sharp rise in oil prices in 1973, for example, there has been a boom in the demand for labor by oil-exporting countries in the Middle East, and this demand has been satisfied by migrant workers from different parts of South and East Asia, as well as non-oil economies of the region. This led to a massive inflow of remittances into the labor-exporting economies, and the associated foreign currency receipts became a major credit item in their balance-of-payments statistics. While these receipts have fluctuated along with changes in policies and macroeconomic conditions in the home countries of workers in the aftermath of the initial boom, one can see a general downtrend in the 1985-89 period due to the recession that oil-exporting economies experienced in the late 1980s with the decline in oil prices (Wahba 1991). Saudi Arabia, for example, lost its ranking as the leading source of remittances to the United States in the mid-1990s when the economic boom kept alive by oil exports finally came to an end. These examples indicate that home countries of migrant workers often experience marked changes in remittance receipts, as the fluctuations in economic activity in host countries cause changes in demand for imported labor and wages received by migrant workers.

In addition to such external shocks, the state of the economy in the migrant workers' own countries is also likely to affect their remittance behavior. These effects may be particularly visible if the economic activity at home is down when it is up in the country of employment, or vice versa. In fact, given the typically different structures of economies sending and receiving migrant workers, the periodicity and 
nature of business cycles would normally be different, with nonmatching ups and downs. Coupled with the typically imperfect nature of capital flows between home and host country economies, inharmonious cyclical movements in host and home economies are likely to imply differences in the rates of return to savings. Therefore, whether there are any empirical regularities between the fluctuations in remittance flows and business cycle characteristics in either the countries hosting guest workers or the countries sending workers is an interesting and important question, because ups and downs in remittance flows may contribute to (or reduce) the intensity of recession or expansion, as pointed out by Buch et al. (2002) and Ratha (2003).

While the answers to this question may, in fact, be very useful in smoothing (or at least preparing for) the fluctuations in macroeconomic balances resulting from variations in the level of remittances, both the business cycles literature and the literature studying remittances and their effects on recipients have surprisingly overlooked this question. Much of the existing literature has focused instead on the relationship between foreign aid and cycles in donor countries, and on how official development assistance affects the growth of recipient countries (for a survey, see Pallage and Robe 2001). ${ }^{7}$ Even though the significance of remittances as a channel for transmitting cyclical fluctuations from one country to the others was noted in such recent papers as Buch et al. (2002) and Ratha (2003), the question has not been empirically tackled or formally investigated except for a few limiteddistribution papers, such as Swamy (1981) and Sayan (2002).

This paper aims to help fill this gap in the literature by documenting some key business cycle properties of workers' remittances received by the Turkish economy. More specifically, the paper seeks an answer to whether there has been a comovement between the remittances that Turkey receives from the large number of Turkish workers living and working in Germany and output cycles in either of these two countries.

The results indicate that the remittances are strongly positively correlated with the Turkish national output, and they are not correlated with the German national output. In other words, remittances sent by Turkish workers are procyclical with the real GDP in Turkey but appear to be acyclical with the German output. This finding becomes particularly important in light of the fact that output fluctuations in Turkey are stronger than those in more advanced economies in general. It is indeed documented in the paper that the real GDP in Turkey is significantly more volatile than that in Germany. At the same time, given that remittances make up a very important source of income for Turkey, remitted earnings of Turkish workers abroad have the potential to play a key role in affecting Turkey's output fluctuations.

\section{Data and Analysis}

In the following sections, business cycle properties of remittances sent by Turkish workers in Germany are analyzed against the behavior of the real outputs of Turkey and Germany using quarterly data between 1987:1 and 2001:4. For the purpose of 
this analysis, fluctuations around the trend of each data series are identified by detrending the series through the Hodrick and Prescott (1980) filter (hereafter, HP filter).

The respective output series for each country was chosen in light of the national income accounting conventions that define GNP (gross national product), or GNI (gross national income) as GDP plus NFI (net factor income from abroad). Because NFI includes net remittance receipts, Turkish GDP and German GNI series leave out remittances sent to Turkey by Turkish workers in Germany. Thus, GDP for Turkey and GNI for Germany would be the more appropriate output measure to analyze the cyclical behavior of real remittances sent home by Turkish workers against the real output in Turkey and Germany.

Nominal GDP series for Turkey and nominal GNI series for Germany in domestic currency terms (Turkish lira for Turkey and deutsche mark for Germany) were taken from the International Monetary Fund's (IMF) International Financial Statistics (IFS) and deflated by the consumer price index (CPI; $1995=100)$, also taken from the IFS. Time series data on total workers' remittances from Turkish workers abroad were obtained from the Turkish central bank's Web site, where remittance flows are regularly reported in current U.S. dollar terms. ${ }^{8}$

Because it was impossible to separate remittances sent in by Turkish workers in Germany from the rest, however, the values in this series were weighted by the shares of Turkish workers in Germany in the corresponding stock of migrant workers from Turkey. The weights used came from time series data on the changing stock of Turkish workers abroad by the country of employment, as reported in Table 1. While this assumption may seem somewhat problematic, it was necessitated by the lack of information on remittances sent from Germany alone. Furthermore, given that most Turkish workers abroad come from economically and socially similar family backgrounds in Turkey, and have similar skill distributions in their country of employment, and that the overwhelming majority of them found employment in other European countries with similar characteristics to Germany, there is no reason to expect that the remittances sent by an average worker substantially differ across countries of employment. Thus, the resulting series may be viewed as an accurate proxy for remittances sent by Turkish workers in Germany.

Total remittances series weighted by shares of workers in Germany was converted first into a quarterly series in Turkish lira terms and deflated by the CPI (with $1995=100$ ) to make the units for remittances and Turkish GDP comparable. The same conversion procedure was then repeated for obtaining a remittances series that is compatible with the German GDP series in real deutsche mark terms.

To investigate the behavior of remittances sent by Turkish workers over different phases of business cycles in Turkey and Germany, the remittances and respective real GDP series need to be detrended first. Detrending makes separating fluctuations around the trend of each data series possible, and this is necessary to identify stylized facts of business cycles, that can be captured by examining the statistical properties of the comovements of deviations of output and time series of 
NOVEMBER-DECEMBER 200473

Table 1

\begin{tabular}{|c|c|c|c|c|c|c|c|c|}
\hline Years & 1987 & 1988 & 1989 & 1990 & 1991 & 1992 & 1993 & 1994 \\
\hline Share & 57.6 & 59.0 & 58.9 & 57.5 & 55.5 & 57.3 & 58.5 & 57.4 \\
\hline Years & 1995 & 1996 & 1997 & 1998 & 1999 & 2000 & 2001 & \\
\hline Share & 56.1 & 58.6 & 59.6 & 60.8 & 63.0 & 63.0 & 62.0 & \\
\hline
\end{tabular}

Source: Aydas (2002).

interest from their respective trends (Kydland and Prescott 1990; Lucas 1977). To identify deviations from (or cyclical fluctuations around) the trend, each data series under consideration here is detrended through the HP filter.

For any given series $y_{t}$, the HP filter separates the trend (growth) component, $\tau_{t}$, of the series from the cyclical component, $c_{t}$, by minimizing the following loss function:

$$
\operatorname{Min}_{g_{t}} \sum_{t=1}^{T}\left(y_{t}-\tau_{t}\right)^{2}+\lambda \sum_{t=2}^{T-1}\left[\left(\tau_{t+1}-\tau_{t}\right)-\left(\tau_{t}-\tau_{t-1}\right)\right]^{2}
$$

where $\lambda$ is a penalty parameter.

Once the cyclical components, $c_{t}$, of real remittances and output series are obtained from the solution of the optimization problem above, the contemporaneous correlations between these two series can be calculated. A positive (negative) contemporaneous correlation is taken to imply that the remittances are procyclical (countercyclical) with the real output series in question. In general, a variable is said to be procyclical (countercyclical) with - the movement of a cyclical component of - the real output if the contemporaneous cross-correlation (cross-correlation at time $t=0$ ) is positive (negative) in the statistically significant sense (Alper 2002; Kydland and Prescott 1990; Pallage and Robe 2001). Procyclicality (countercyclicality) in this context indicates the tendency of real remittances to move above trend, when the corresponding real output variable is above (below) its respective trend.

The next section reports contemporaneous cross-correlations as well as asynchronous correlations between the cyclical components of respective series calculated after shifting the series backward or forward for up to four quarters. These correlation coefficients enable one to identify possible phase shifts by looking at how early or how late the highest correlation appears relative to the contempora- 
neous period (Pallage and Robe 2001). If the largest (in absolute value) significant correlation between a particular series and the real output occurs when the series is shifted backward (forward), then the variable is said to be leading (lagging) the cycle. If, for example, the largest significant correlation coefficient between real output and a procyclical series is obtained when that series is shifted back (forward) by $q$ quarters, then the series is understood to have a tendency to peak at about $q$ quarters before (after) the real output peaks. In such a case, the series is said to lead (lag) the (output) cycle.

To be more precise, the comovement between real remittances and Turkish and German real outputs can be evaluated through the following steps:

1. Calculate correlation coefficients between the real output in country $C(C \in$ \{Turkey, Germany\}) and the original as well as the shifted back/forward versions of the real remittances series-in the appropriate currency.

2. Check the statistical significance of correlation coefficients calculated, and identify the appropriate cell of Table 2, characterizing the nature of these coefficients.

\section{Comovements of Real Remittances with Turkish and German Outputs}

In detrending each series of interest here, the value of $\lambda$ was taken to be equal to 1,600 , because this is the value commonly used in the literature for quarterly data, as suggested by Hodrick and Prescott (1980). Throughout the analysis, the logarithms of the series were used so as to focus on percentage deviations from trend. Figures 1 and 2 illustrate the original series and respective trends extracted using the HP filter with $\lambda=1,600$ for the case of German output and remittances of Turkish workers in Germany in real deutsche mark terms.

Cross-correlations between the cyclical components of real remittances and corresponding output series were then calculated by using the HP-filtered data, and by shifting the cyclical component of real remittances by one to four quarters in both directions. To evaluate the statistical significance of these correlation coefficients, the null hypothesis that the unknown population correlation, $\rho$, is equal to zero was tested against the two-sided alternative that $\mathrm{H}_{\mathrm{A}}: \rho \neq 0$, using the correlation coefficients, $r$, calculated from the relevant samples made up of sixty observations covering 1987:1-2001:4. In deciding whether to reject the null hypothesis, the critical $t$-values were determined according to

$$
t=r \sqrt{\frac{n-2}{1-r^{2}}},
$$

where $n$ is the number of observations in each sample. With $n=60$, this value is expected to fall with a 95 percent probability into the $[-2,2]$ bracket, when the null hypothesis is true. By rearranging terms in Equation (2), one obtains 
Table 2

\section{Statistical Significance of Correlation Coefficients}

\begin{tabular}{|c|c|c|}
\hline & \multicolumn{2}{|c|}{ Noncontemporaneous correlation coefficients } \\
\hline & Significant & Not significant \\
\hline \multicolumn{3}{|c|}{ Contemporaneous correlation coefficients } \\
\hline Significant & $\begin{array}{l}\text { The real remittances are } \\
\text { either countercyclical or } \\
\text { procyclical and move } \\
\text { synchronously with, or } \\
\text { lead/lag, the output } \\
\text { cycle.* }\end{array}$ & $\begin{array}{l}\text { The real remittances move } \\
\text { synchronously with the } \\
\text { output in either a } \\
\text { procyclical or } \\
\text { countercyclical fashion. }\end{array}$ \\
\hline Not significant & $\begin{array}{l}\text { The real remittances move } \\
\text { asynchronously with the } \\
\text { output, and lead or lag } \\
\text { the output cycle.* }\end{array}$ & The series are acyclical. \\
\hline
\end{tabular}

\section{Figure 1. Real GDP of Germany and Its Trend}

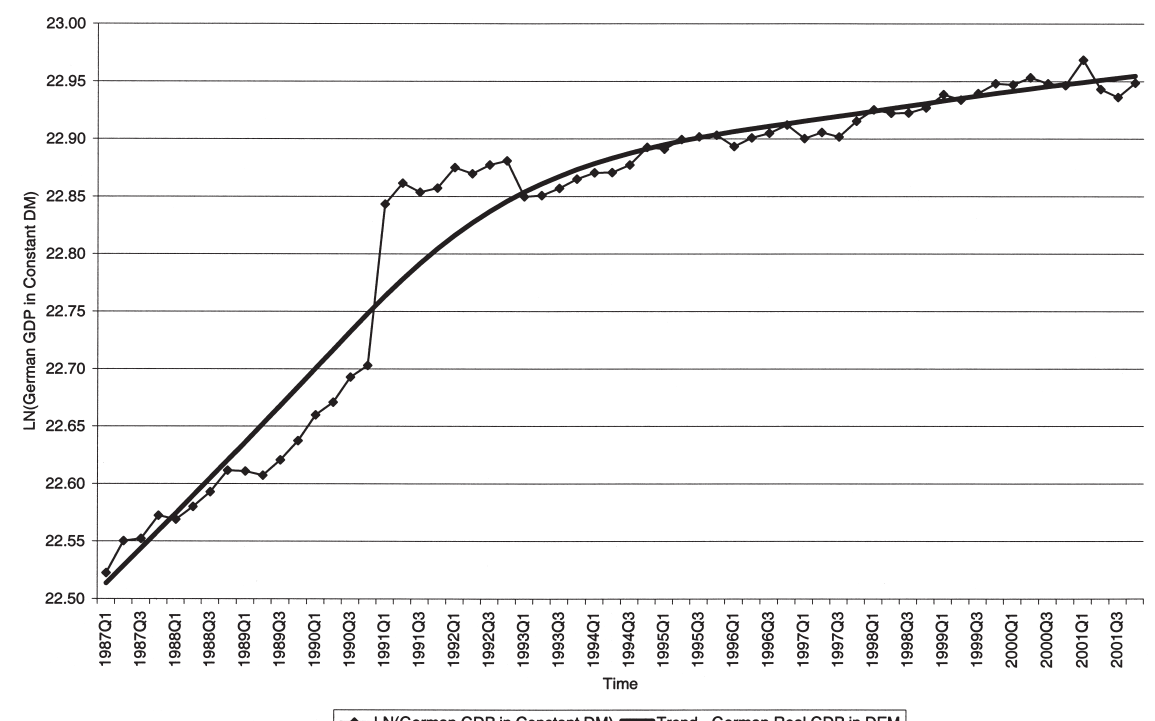


Figure 2. Real Remittances in Deutsche Mark Series and Its Trend

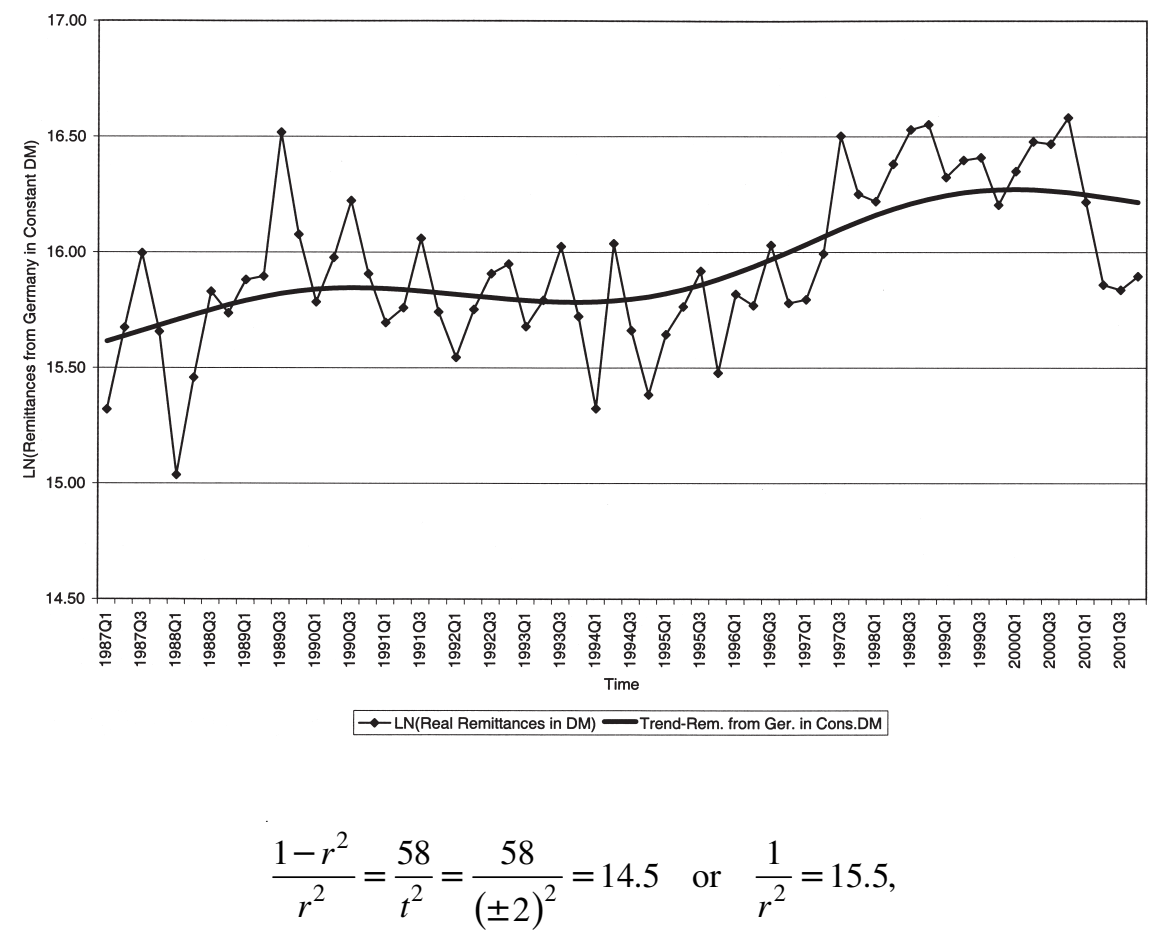

implying that $r= \pm(15.5)^{-0.5} \cong \pm 0.254$. This means that correlation coefficients falling outside the $[-0.254,0.254]$ range will require that the null hypothesis be rejected; that is, they will be considered significant statistically. The cross-correlations between the cyclical components of real remittances and output series calculated by using the HP-filtered data with $\lambda=1,600$ are given in Tables 3 and 4 .

The results reported in the tables indicate the following:

Comparative volatility of outputs: The output in Turkey is more volatile than the German output. Standard deviation of real GDP in Turkey is 20 percent over the 1987-2001 period, whereas standard deviation of real GNI in Germany is only 6 percent.

Volatility of remittances: Remittance flows from Turkish workers in Germany are quite volatile. Volatility is about 26 percent when measured in constant Turkish lira terms, and it is 29 percent when measured in constant deutsche mark terms.

Comovement of remittance flows with the Turkish output: Turkish workers' remittances are procyclical with the GDP in Turkey. The cyclical component of real remittances series is strongly positively correlated with the cyclical component of Turkish real GDP. When plugged into Equation (2), the contemporaneous correlation coefficient value of 0.51 (Table 3 ) implies a $t$-value of about 4.5, which comfortably falls outside the critical region, indicating that the remittances are 
Table 3

Cross-Correlations Between Remittances and Turkish GDP (in real Turkish lira terms)

\begin{tabular}{lcc} 
Variable & $X_{t} \equiv \mathrm{GDP}_{t}$ & $X_{t} \equiv$ remittances $_{t}$ \\
\hline & 0.93 & $0.53^{1}$ \\
$X_{t-4}$ & -0.04 & -0.21 \\
$X_{t-3}$ & -0.85 & $-0.47^{1}$ \\
$X_{t-2}$ & -0.01 & 0.16 \\
$X_{t-1}$ & 1.00 & $0.51^{1}$ \\
$X_{t}$ & -0.01 & -0.17 \\
$X_{t+1}$ & -0.85 & $-0.39^{1}$ \\
$X_{t+2}$ & -0.04 & 0.17 \\
$X_{t+3}$ & 0.93 & $0.47^{1}$ \\
$X_{t+4}$ & 20 & 26 \\
Volatility ${ }^{2}$ (percent) & \\
\multicolumn{2}{l}{ Notes: ${ }^{1}$ Shows the coefficients that are statistically significant; ${ }^{2}$ percentage standard } \\
deviation of the cyclical component of the series.
\end{tabular}

Table 4

Cross-Correlations Between Remittances and German GNI (in real deutsche mark terms)

\begin{tabular}{lcc} 
Variable & $X_{t} \equiv \mathrm{GDP}_{t}$ & $X_{t} \equiv$ remittances $_{t}{ }^{1}$ \\
\hline$X_{t-4}$ & 0.24 & 0.09 \\
$X_{t-3}$ & 0.39 & 0.02 \\
$X_{t-2}$ & 0.55 & -0.05 \\
$X_{t-1}$ & 0.74 & -0.12 \\
$X_{t}$ & 1.00 & -0.10 \\
$X_{t+1}$ & 0.74 & -0.09 \\
$X_{t+2}$ & 0.55 & -0.06 \\
$X_{t+3}$ & 0.39 & -0.04 \\
$X_{t+4}$ & 0.24 & -0.06 \\
Volatility $^{2}$ (percent) & 6 & 29
\end{tabular}

Notes: ${ }^{1}$ No correlation coefficient in this column is statistically significant by the criterion introduced through Equation (2); ${ }^{2}$ percentage standard deviation of the cyclical component of the series. 
procyclical. Looking at the phase shifts, the largest correlation occurs when the real remittances series is shifted back by four quarters. Given that the corresponding coefficient value of 0.53 is significant, the remittances appear to be leading the output by a year. While it is certainly perceivable that the real GDP peaks about a year after remittances peak, this value is very close to the value of contemporaneous correlation coefficient. The affinity of these two values makes it difficult to rule out the possibility that the real remittances may be almost synchronous with the real GDP in Turkey. Therefore, the contemporaneous correlation between output and real remittances, and the correlation between output and real remittances lagged by four quarters, do not really provide an easy choice about whether real remittances are leading the Turkish GDP by four quarters or are synchronous with it. Furthermore, the next largest positive correlation coefficient is a close 0.47, signaling that the real remittances may even be lagging the output in Turkey by four quarters, and making it even more difficult to pick the relevant phase shift. Yet it appears safe to argue that there is a strong similarity between the cycles of real output in Turkey and remittances from Germany in constant Turkish lira terms, hinting that real output in Turkey moves in cycles of similar length: When the remittances series is shifted by about four quarters in either direction, it retains its similarity to the output cycle. This, in turn, implies that there is a strong comovement between remittances and output, or that Turkish workers in Germany closely watch developments in Turkey and, accordingly, respond to the state of the Turkish economy. In fact, Turkey suffered an additional blow when the 1990s' rising trend of remittances turned down following the severe economic crises that the country faced in 1999 and the early 2000s (Ratha 2003).

Comovement of remittance flows with the German output: Turkish workers' remittances are acyclical with the real output in Germany. Most of the correlation coefficients between the cyclical component of real remittances by Turkish workers and the cyclical component of the real GNI in Germany turned out to be negative, indicating that the Turkish workers' response to an upturn (downturn) in the German business cycle is to begin reducing (increasing) remittances sent home roughly within a year. While such a behavior appears sensible-as it implies that when the German economy is growing, Turkish workers find it more profitable to keep their savings in Germany-none of the calculated coefficients, including the contemporaneous coefficient, is statistically significant (Table 4). Even though this is a very interesting finding, it must be evaluated with caution, because it is based on remittances data constructed under certain assumptions. Remembering that the absence of data on remittances directly sent from Germany made it necessary to construct the underlying series by weighting the total remittance receipts of Turkey with the share of Turkish workers in Germany, the validity of this result rests upon the realism of the assumption that the remittance behavior of workers in Germany accurately mimics the typical remittance behavior of all Turkish workers abroad. ${ }^{9}$ Even though there seems to be no reason to assume otherwise, this assumption admittedly requires looking into additional evidence to justify. 


\section{Conclusion}

The previously discussed results revealed that the real GDP in Turkey and the real remittance flows from Germany are much more volatile than the German output. They also indicated that these real remittances are procyclical with the GDP in Turkey are, but acyclical with the German GNI.

Even though Turkish workers could be expected to respond to an upturn (downturn) in the German business cycle by changing their remittance behavior accordingly with the changes in relative returns to savings kept in Germany during the growth/expansion (recession/contraction) phases of the German cycle, the evidence obtained here did not indicate this to be the case. One could also hypothesize that the earnings of Turkish workers in Germany would increase during booms in the German economy and decrease during crises, implying a positive relationship between remittances and growth of German output, but the results did not produce any evidence to this effect either. As interesting as they are, it is difficult to say whether these results, pointing to the acyclicality of Turkish workers' remittances with the output in Germany, were due to the problems with the data used here or to the existence of other incentives affecting the remittance behavior of Turkish workers more strongly than the effects of business cycles on returns to savings in Germany. Resolving this issue is certainly an important challenge requiring repeated calculation of the correlation coefficients with a data set that is tested for higher accuracy in the future. Yet the results concerning the nature of comovements between real remittances and Turkish output could also provide some help.

The investigation of the cyclical behavior of Turkish workers' remittances with respect to the Turkish output has indeed produced results that are relatively more revealing. Given the strength of the positive contemporaneous correlation of the cyclical component of real remittances from Germany with the cyclical component of Turkish GDP, the first series was found to be undoubtedly procyclical with the second. While correlation coefficients obtained after the phase shifts proved difficult to interpret, leaving the question of whether remittances are synchronous with or leading/lagging the Turkish output unanswered, one can safely argue that there is a strong comovement between remittances and output. This implies that Turkish workers in Germany closely watch developments in Turkey, forming accurate expectations about the state of the Turkish economy or quickly and positively responding to its movements. In light of the asynchronous nature of Turkish and German cycles resulting from the considerably higher volatility of Turkish output, one might offer this seemingly deeper focus of Turkish workers on the developments in the Turkish economy as a reason for the observed acyclicality of remittances with the German output.

As for the implications of this behavior for the Turkish economy, the remittance flows provide opportunities to boost an upward trend in the Turkish economy, but they might easily prove to be a serious challenge to be dealt with during times 
of downturns, as the decline in remittances might further contribute to a recession. In other words, the rather volatile nature of remittances, coupled with the procyclicality of remittance receipts, certainly acts to intensify the volatility of Turkish output. Exploring the welfare and growth implications of this added volatility in greater detail requires further investigation.

\section{Notes}

1. Greece, Portugal, and Spain were among the countries that sent large numbers of migrant workers to the rest of Europe, and later joined the European Union.

2. Remittances are typically defined as monetary transfers made by workers who lived abroad for more than a year.

3. The choices available to the workers range from sending the bare minimum that is necessary to cover the basic needs of dependents or other relatives left behind, to transferring the entire amount of earnings after deducting workers' living expenses. Wahba (1991) called the first "fixed" remittances and the second "potential" remittances.

4. See Chami et al. (2003) for an unconventional view of remittances.

5. "Top Remittance Receiving Countries in 1999." AFP Exchange 22, no. 3 (MayJune), 2002, p. 70.

6. In fact, the relatively low volatility of remittances has induced some emerging market economies to use them as collateral in negotiating lower rates on loans they seek from international capital markets. Countries such as Brazil, Mexico, and Turkey have all raised external financing by using securities backed by remittances they expected to receive in the future (Ratha 2003). Given the stringent nature of the terms on back payments of such lower interest and longer maturity loans, however, would add to the severity of consequences of unexpected drops in remittances.

7. This is particularly surprising in light of the fact that remittance receipts have exceeded official development assistance for most of the 1990s (Ratha 2003).

8. Seasonally adjusted series were not used, as repeated analysis with series that are seasonally adjusted through different methods produced incompatible and often inconsistent results.

9. It must be noted that the use of similarly constructed real remittances series in Turkish lira terms, while analyzing the cyclicality of remittances vis-à-vis the Turkish output, does not seriously challenge the validity of results on the nature of the comovements between these two series.

\section{References}

Alper, E. 2002. "Business Cycles, Excess Volatility, and Capital Flows: Evidence from Mexico and Turkey." Emerging Markets Finance and Trade 38, no. 4 (July-August): 25-58.

Aydas, O.T. 2002. “Determinants of Workers' Remittances: Evidence from Turkey.” Master's thesis, Bilkent University, Ankara.

Buch, C.M.; A. Kuckulenz; and M. Le Manchec. 2002. "Worker Remittances and Capital Flows.” Kiel Institute for World Economics, Discussion Paper No. 1130, Kiel, Germany.

Chami, R.; C. Fullenkamp; and S. Jahjah. 2003. "Are Immigrant Remittance Flows a Source of Capital for Development?" International Monetary Fund, Working Paper No. WP/03/ 189, Washington, DC. 
Collinson, S. 1993. Europe and International Migration. London: Royal Institute of International Affairs.

El-Sakka, M.I.T., and R. Mcnabb. 1999. "The Macroeconomic Determinants of Emigrant Remittances." World Development 27, no. 8: 1493-1502.

Faini, R. 1994. "Workers' Remittances and the Real Exchange Rate: A Quantitative Framework." Journal of Population Economics 7, no. 2: 235-245.

Giubilaro, D. 1997. Migration from the Maghreb and Migration Pressures: Current Situation and Future Prospects. Geneva: International Labour Office.

Glytsos, N.P. 1993. "Measuring the Income Effect of Migrant Remittances: A Methodological Approach Applied to Greece." Economic Development and Cultural Change 42, no. 1: 131-168.

—. 2002. "The Role of Migrant Remittances in Development: Evidence from Mediterranean Countries." International Migration 40, no. 1: 5-26.

Hodrick, R.J.; and E.C. Prescott. 1980. "Postwar U.S. Business Cycles: An Empirical Investigation.” Discussion Paper No. 451, Carnegie Mellon University, Pittsburgh.

Kydland, F.E., and E. Prescott. 1990. "Business Cycles: Real Facts and a Monetary Myth." Federal Reserve Bank of Minneapolis Quarterly Review 14, no. 2: 3-18.

Lianos, T.P. 1997. "Factors Determining Migrant Remittances: The Case of Greece." International Migration Review 31, no. 1: 72-87.

Lucas, R.E. 1977. "Understanding Business Cycles." In Stabilization of the Domestic and International Economy, ed. K. Brunner and A.H. Meltzer, pp. 7-29. Amsterdam: NorthHolland.

Neyapti, B. 2004. “Trends in Workers' Remittances: A Worldwide Overview." Emerging Markets Finance and Trade 40, no. 2 (March-April): 83-90.

Pallage, S., and M.A. Robe. 2001. "Foreign Aid and the Business Cycle." Review of International Economics 9, no. 4: 641-672.

Ratha, D. 2003. "Workers' Remittances: An Important and Stable Source of External Development Finance." In Global Development Finance: Striving for Stability in Development Finance, pp. 157-175. Washington, DC: World Bank.

Sayan, S. 2002. "Cyclicality of Remittance Flows and Business Cycle Characteristics in Host and Home Countries of Migrant Workers: The Case of Remittances of Turkish Workers in Germany." Paper presented at the eighth annual meeting of the Economic Research Forum, Cairo, January 15-17.

Straubhaar, T. 1985. "Der Zahlungsbilanzeffect der Devisentransfers ausgewanderter Aebeitskrafte fur ihre Herkunftslander" [The Balance of Payments Effect for Their Home Country of Migrant Workers' Remittances]. Jahrbucher fur Nationalokonomie und Statistik 200, no. 3: 280-297.

- 1986. "The Determinants of Workers' Remittances: The Case of Turkey." Weltwirtschaftliches Archiv 122, no. 4: 728-740.

Swamy, G. 1981. "International Migrant Workers' Remittances: Issues and Prospects.” World Bank, Staff Working Paper No. 481, Washington, DC.

Wahba, S. 1991. "What Determines Workers' Remittances." Finance and Development 28, no. 4: 41-44.

To order reprints, call 1-800-352-2210; outside the United States, call 717-632-3535. 